\title{
SEROPREVALENCE OF BOVINE VIRAL DIARRHOEA VIRUS IN HUNGARY - SITUATION BEFORE LAUNCHING AN ERADICATION CAMPAIGN
}

\author{
Csaba KÖVÁGÓ ${ }^{1 *}$, Petra FORGÁCH ${ }^{2}$, Ágnes SZABÁRA ${ }^{3}$, Míra MÁNDOKI ${ }^{4}$, \\ Ákos HORNYÁK ${ }^{5}$, Conor DUIGNAN ${ }^{4}$, Erzsébet PÁSZTINÉ GERE ${ }^{1}$ and Miklós RUSVAI ${ }^{4}$ \\ ${ }^{1}$ Department of Pharmacology and Toxicology, ${ }^{2}$ Department of Microbiology and Infec- \\ tious Diseases, ${ }^{3}$ Department of State Veterinary Medicine and Agricultural Economics, \\ ${ }^{4}$ Department of Pathology, Faculty of Veterinary Medicine, Szent István University, \\ István u. 2, H-1078 Budapest, Hungary; ${ }^{5}$ National Food Chain Safety Office of the \\ Veterinary Directorate, Budapest, Hungary
}

(Received 27 November 2014; accepted 17 February 2015)

Bovine viral diarrhoea (BVD) is a viral disease appearing in various forms and causing high economic losses in the cattle stocks of Hungary. The aim of the present study was to determine the prevalence of bovine viral diarrhoea virus (BVDV) in Hungary through a monitoring survey carried out on samples collected in cattle-keeping units throughout the country. Since no such survey had been carried out in Hungary during the last thirty years, our study may serve as a basis for later monitoring investigations aimed at following the progress of an expected eradication campaign of BVD. The tests were carried out using an ELISA method, on a total of 1200 blood samples submitted from 54 cattle herds. The herds had not been vaccinated against BVDV before the sampling. Out of the 1200 samples, 521 proved to be positive (43.4\%), 40 gave doubtful result (3.3\%) and 639 were negative (53.3\%). In some stocks the samples were collected from cows having completed several lactation periods, and therefore the seronegativity indicates the BVDV-free status of the given stock. Moreover, among the positive herds we found a few where the seropositivity rate was rather low $(<5 \%)$. According to the results of the survey, a rather high portion (about one third) of the cattle-keeping units of Hungary can be regarded as BVDV free, which ratio is much higher than had been expected on the basis of surveys carried out on a lower number of samples and in smaller regions of the country. Hence, the chances of an eradication campaign launched in the near future, or carried out parallel to the IBR eradication programme, are better than previously expected.

Key words: Bovine viral diarrhoea virus, eradication, serosurvey

Due to the special features of the infection, bovine viral diarrhoea (BVD) is one of the leading health problems of cattle in most European countries where it is present. Infection with the virus can cause several diseases ranging from

\footnotetext{
"Corresponding author; E-mail: kovago.csaba@aotk.szie.hu; Phone: 0036 (1) 478-4167
} 
subclinical infection and seroconversion to fatal mucosal disease, and including peracute diarrhoea and reproductive failure. Besides being a source of direct losses by causing enteritis in calves (as reflected in the name of the disease), bovine viral diarrhoea virus (BVDV) also has a fetopathic ability, hence reducing the reproductive capacity of a herd.

BVDV is a single-stranded RNA virus that belongs to the Pestivirus genus of the Flaviviridae family. It has two biotypes: cytopathic (CP) and non-cytopathic (NCP). If the non-cytopathic type crosses the placenta to enter the fetus, the newborn calf will be persistently infected (PI) post partum, and these animals are critical to the spread of the virus, since they are a major source of infection in a herd shedding the virus in large amounts in their secretions and excretions, causing seroconversion in healthy herdmates and reproductive failure in pregnant cows. The virus may also be spread by biting insects, fomites (enabling iatrogenic transmission), semen (highly important in farms using assisted reproduction), contact with other animals and potentially by discharges from the reproductive tract of infected cows. A PI female remaining clinically normal for many breeding seasons can produce PI lineage continuing for several generations, which will shed the virus indefinitely (Radostits and Done, 2007; Kahn and Line, 2010).

The cytopathic strain is most dangerous when it enters a PI animal, resulting in mucosal disease (MD). CP is a mutant of the NCP strain within PI animals (Goens, 2002).

In addition to strain classification, antigen diversity divides the virus into BVDV types 1 and 2, with BVDV-1 comprising many important subgenotypes. The single European market presents an opportunity for a serotype matrix to occur across Europe and present a major problem for vaccination and surveillance for the virus (Graham et al., 2001; Hamers et al., 2001).

The costs incurred by farms raising suckler herds infected with BVDV are due to abortion, congenital defects, stillbirths, increased neonatal mortality, reduced immunocompetence, growth retardation, reproductive disorders, early disposal of PI animals, and deaths from mucosal disease (Radostits and Done, 2007).

The cost of infection depends on statistical weighting towards a given disease impact, e.g. production/efficiency or animal welfare. Quantitative analysis of BVDV relies almost entirely on economic aspects, overlooking the impact of animal welfare, e.g. pain and stress, and their impact on feed conversion ratios (Lindberg and Alenius, 1999).

Since in Hungary, before this study, no overall representative surveys had been carried out to establish the prevalence rate of BVDV, we planned to carry out a serosurvey using blood samples from different large-scale farms throughout the country. We decided to use the indirect method (serology) to demonstrate the presence of the virus in a certain stock, because antibodies persist longer and give more informative results on prevalence of the virus. Our data are aimed to help eradication of the virus, which has already been started in some stocks on a 
voluntary basis. We wanted to know if there were any non-infected stocks, which might serve as 'nucleus stocks' to provide virus-free animals to replace heavily infected stocks in which the high seropositivity rate indicates active circulation of BVDV. Therefore, we were interested in the prevalence of the virus more on herd level than on the level of individual animals.

Published European surveys for determining the herd-level prevalence of BVDV infection are usually based on samples of bulk milk or those taken from targeted age groups (spot samples). For countries that have implemented systematic control, Tables 1 and 2 include surveys performed before or at the beginning of the schemes (Greiser-Wilke et al., 2003; Vilcek et al., 2003; Hagglund et al., 2006; Gulliksen et al., 2009; Ridpath, 2010).

\section{Table 1}

BVD control status in some countries of Europe (data are not available from all countries)

\begin{tabular}{lccc}
\hline \multirow{2}{*}{ Country } & Period & \multicolumn{2}{c}{ Antibody prevalence } \\
\cline { 3 - 4 } & & Herd level (\%) & Animal level (\%) \\
\hline Belgium & & 100 & 65.50 \\
Denmark & 1988 & 100 & 64.40 \\
Germany & $1993-1994$ & & 58.20 \\
Lithuania & $1997-2001$ & & \\
Poland & & 100 & insemination centres) \\
& 2000 & & 69 \\
Slovakia & 2010 & & 1.1 \\
Switzerland & $1985-1986$ & & 64.90 \\
United Kingdom & 1991 & 91 (bulk milk samples) \\
Sweden & 2006 & 38 (bulk milk samples) & \\
Sweden & & & \\
\hline
\end{tabular}

Table 2

BVD seropositivity and antigen prevalence in some countries of Europe (data are not available from all countries)

\begin{tabular}{lccc}
\hline Country & Period & $\begin{array}{c}\text { Herd antibody } \\
\text { prevalence (\%) }\end{array}$ & $\begin{array}{c}\text { Herd virus/Active infection } \\
\text { prevalence* }(\%)\end{array}$ \\
\hline Austria & $1996-1998$ & & 1 \\
Denmark & 1994 & & 39 \\
Estonia & $1993-1995,1997-1998$, & & 46,16, \\
& $1999-2000$ & 1 & 18 \\
Finland & 1993 & 95.40 & 65.50 \\
England and Wales & 1996 & 99 & 49.60 \\
Northern Ireland & 1999 & 37 & 7.10 \\
Norway & 1993 & & 51 \\
Sweden & 1993 & & \\
\hline
\end{tabular}




\section{Materials and methods}

Herds. The sample population was diverse geographically (see Fig. 1) and in terms of the age, sex and purpose of the animals: Sera for analysis were taken from calves, heifers, cows and bulls from 54 herds throughout Hungary. Some farms owned herds at multiple premises sampled in the study. None of the herds applied vaccination against BVD.

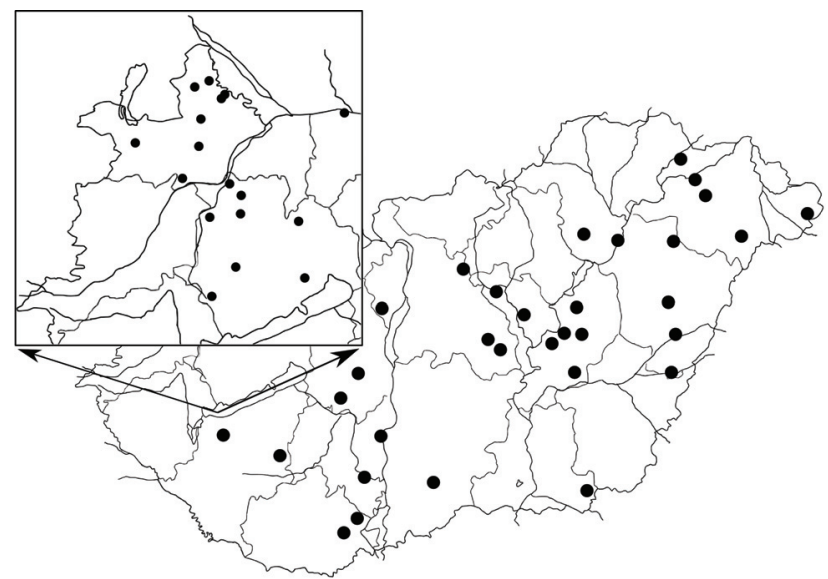

Fig. 1. Geographical distribution of the herds sampled (the north-western part of Hungary is enlarged because the herds were too close to each other)

Blood samples. Blood samples were obtained via jugular venipuncture and allowed to clot. Serum was isolated via centrifugation at $1000 \mathrm{~g}$ for $3 \mathrm{~min}$, removed from the samples and stored at $-20{ }^{\circ} \mathrm{C}$ until analysis.

Serological tests. BVD antibodies were identified in the sera using an ELISA test kit (IDEXX HerdChek BVDV Antibody Test Kit, IDEXX Laboratories Inc., Westbrook, ME, USA) according the manufacturer's instructions.

\section{Results}

The abridged results of the survey are shown in Table 3, with herds grouped according to disease prevalence. The cumulative results of the survey are presented in Table 4.

Group 1. Herds of this subset may be classified as truly seropositive for BVD. Total or near-total seropositivity was exhibited. These are 'problem herds' which would benefit from the implementation of an eradication strategy. In farms where age data reveal that all positive animals were cows, these animals may be descendants of animals that were exposed to a PI animal. The disease 
will perpetuate in these farms unless all infected stock is replaced. It is also possible that such farms used a live attenuated vaccine in the past and that this vaccine strain causes antibody generation in subsequent offspring. It is reported that such a strain was widely used in Hungary in the 1990s, resulting in rapid spread of the disease through herds, since it was demonstrated that live vaccine virus can cross the placenta (Orban et al., 1983). Pregnant animals vaccinated during this period were also affected, with those vaccinated in the first half of gestation transmitting the virus to their offspring. This resulted in the birth of very high numbers of PI animals. Other explanations include vaccination without documentation, vaccination when under the care of another veterinarian and not informing the current veterinarian of vaccination status, seropositive semen (impossible as all semen is screened for BVD), or seropositive bull.

Group 2. This cohort showed variable rates of disease throughout various herds and geographical regions. It is possible that these animals have PI offspring each year which propagate the disease through other calves. Also, these farms may have purchased infected animals or have some breeding animals that were exposed to the disease at various stages of gestation.

Group 3. These herds display very low seropositivity: one individual testing positive or questionable. In a sample size of 1200 animals, this low prevalence may be interpreted as test error as it is within the ELISA error range. These herds should be retested to increase the reliability of their data.

Group 4. The results from these herds can be regarded as statistically invalid due to lack of data and a sample size of low statistical validity. The results may be accurate for the individual herd but are discounted from the study as their inclusion would induce artificially seronegative skewed herd-level seroprevalence.

Group 5. BVD-free status in these herds is highly probable. Large populations were sampled but no age data were recorded, which reduces the degree of certainty with which results can be analysed.

Group 6. The animals sampled in this group were of sufficient age to have been exposed to the virus if it had been present in their environment for a clinically significant time period. In addition, the sample sizes at these locations were large enough to provide statistical validity and thus these farms could conclusively be branded 'BVD-free'.

\section{Discussion}

Considering BVDV a production-limiting disease (in the same manner as Johne's disease, neosporosis or enzootic bovine leukosis), the losses caused by it can be described as direct production losses (reduced milk yield on dairy farms, reduced slaughter value of beef cattle, abortion and reproductive losses) and treatment costs (veterinary and medication costs, increased labour demands) (Chi et al., 2002). 


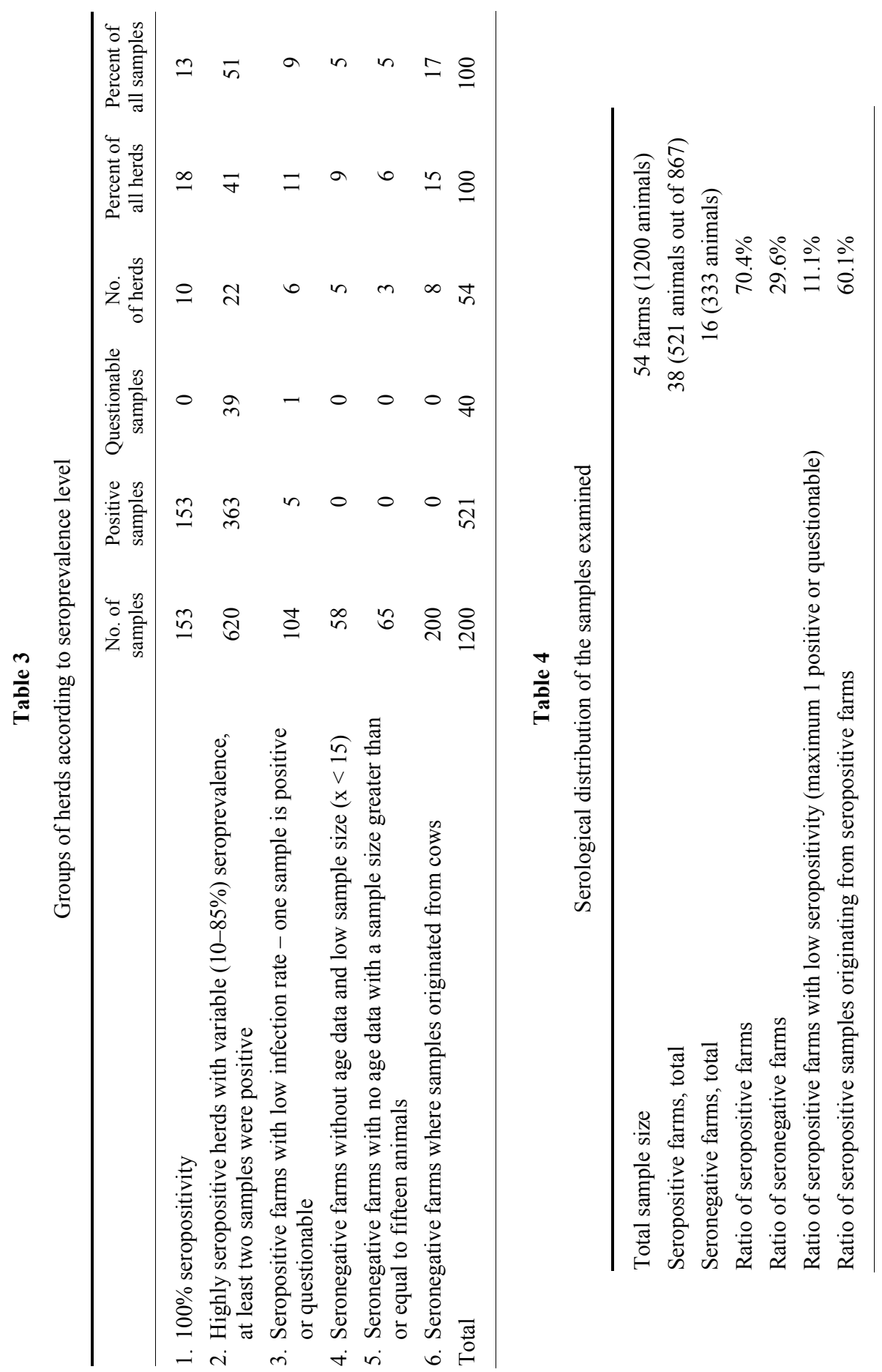


Losses from BVDV outbreaks concomitant with other diseases or due to high mortality caused by a BVDV strain can be in excess of $€ 340$ per cow in the outbreak herd (Houe, 2003). For beef herds a mean loss of $€ 54$ per cow and per year has been calculated. In the United Kingdom, Denmark and Norway, where the disease is endemic, national losses at population level are estimated to be between $€ 8.5$ and $€ 34$ per calving (Houe, 1999). Additionally, in Scotland BVD outbreak losses (estimated at $£ 37$ per cow) are compounded by the loss of premiums awarded to herds with BVD-free status (Gunn et al., 2004). The economic losses caused by BVDV infection on herd and national level are estimated to be high (Ózsvári et al., 2001; Majer et al., 2014).

The BVDV surveillance, control and eradication measures used in other European countries are influential in shaping Hungary's own BVDV strategy (Szabára and Ózsvári, 2013). Vaccination against the virus has questionable efficacy in preventing fetal infection, as the birth of PI calves has been demonstrated in vaccinated herds. Researchers have shown that because $100 \%$ efficacy is required to prevent infection when a herd is exposed to the disease, vaccination does not reduce the prevalence or incidence of BVDV (Lindberg et al., 2006). In preventing macro- and microeconomic losses due to the virus, eradication and control are more effective than the prevention of clinical signs by vaccination (Brock, 2004). Prevention of the disease in infected animals is ineffective in controlling transmission. Therefore, the most effective means of reducing the threat of BVDV is an eradication programme. Persistently infected animals must be eliminated to prevent fetal infection (Lindberg and Alenius, 1999; Ridpath, 2010).

Our results suggest that the seropositivity rate on individual level is $43.4 \%$ (521 seropositive animals from 1200 sampled). If we compare this level to other countries, we find that it is higher then it had been in the Scandinavian countries prior launching the eradication campaign, but lower then it was in certain regions of Austria or Denmark (Greiser-Wilke et al., 2003).

The calculation of seropositivity on herd level shows that $29.6 \%$ of the investigated farms (16 out of 54 farms) were not infected (Table 4). The ratio of seronegative farms is important, since these herds may serve as sources of animal replacement, because during an eradication programme only animals from BVD-free stocks can be introduced to farms where the programme has started. Hence, completely seronegative herds should be used as market seeds. The proprietors of these herds can demand higher premiums for their stock as sales come without the risk of BVD propagation. The monetary value of the herd is enhanced by BVD-free status as various countries among Hungary's neighbours screen for BVD when importing stock. Seronegativity guarantees export to these countries, which is particularly valuable for farmers wishing to establish such trade links.

Furthermore, there are quite a few positive herds $(11.1 \%)$ where the seropositivity rate is extremely low (one out of 15-20 samples is positive or questionable), which either means that the test result could be false and the test has to 
be repeated (especially if the OD value was close to the positivity margin) or the virus is freshly introduced into the stock. In these herds, identification and selection of PI animals may be carried out (by PCR from peripheral lymphocytes or by Ag ELISA from ear notches), and the removal of PI animals may result in successful eradication of BVD from the herd.

The age of the tested animals should also be taken into consideration. The older the tested animals, the more reliable the data are. Cows had more time to get the infection than 6-8 months old calves. Therefore, if the sera of the cows are negative, the herd is most probably negative, too. In farms where age data reveal that all positive animals were cows, these animals may be descendants of animals that had been exposed to a PI animal. The infection will perpetuate in these farms unless all infected stock is replaced. It is also possible that such farms used a live attenuated vaccine in the past and that this vaccine virus strain caused antibody generation in subsequent offspring. Such a strain was widely used in Hungary in the 1990s to successfully prevent the clinical symptoms of the disease in the herds, but if pregnant animals were vaccinated in the first half of gestation, they transmitted the virus to their offspring. This resulted in the birth of very high numbers of PI animals.

If the seropositivity rate is very high within a herd, then eradication by the test and cull method is not possible. In this case only total replacement of the stock can be effective, or the calves should be separated from the cows as soon as possible, tested for their PI status (from ear notches) and raised on a separate farm. The heifers raised in this new, separated stock should not be mixed to the cows. This is possible if a farm has more than one location.

Farms in which multiple premises were tested and the results showed subsets of seropositivity and seronegativity should designate the seronegative herds as breeding stock. Using offspring from these herds will allow the farm to phase out BVD completely without having to pay higher prices for guaranteed BVDfree stock. Such farms must also prevent exposure to disease by purchasing animals only from other BVD-free herds and not allowing their animals to mix with those of undefined or BVD-positive herd status.

BVD-free herds must prioritise protection of their status. This requires the design of disease prevention protocols ideally including breeding, animal purchase and stock replacement, as well as herd and operator hygiene policies (Laureyns et al., 2010).

\section{References}

Brock, K. V. (2004): Strategies for the control and prevention of bovine viral diarrhea virus. Vet. Clin. North Am. Food Anim. Pract. 20, 171-180.

Chi, J., VanLeeuwen, J. A., Weersink, A. and Keefe, G. P. (2002): Direct production losses and treatment costs from bovine viral diarrhoea virus, bovine leukosis virus, Mycobacterium avium subspecies paratuberculosis, and Neospora caninum. Prev. Vet. Med. 55, 137-153.

Goens, S. D. (2002): The evolution of bovine viral diarrhea: a review. Can. Vet. J. 43, 946-954. 
Graham, D. A., McLaren, I. E., Brittain, D. and O’Reilly, P. J. (2001): Genetic typing of ruminant pestivirus strains from Northern Ireland and the Republic of Ireland. Res. Vet. Sci. 71, 127-134.

Greiser-Wilke, I., Grummer, B. and Moennig, V. (2003): Bovine viral diarrhoea eradication and control programmes in Europe. Biologicals 31, 113-118.

Gulliksen, S. M., Jor, E., Lie, K. I., Loken, T., Akerstedt, J. and Osteras, O. (2009): Respiratory infections in Norwegian dairy calves. J. Dairy Sci. 92, 5139-5146.

Gunn, G. J., Stott, A. W. and Humphry, R. W. (2004): Modelling and costing BVD outbreaks in beef herds. Vet. J. 167, 143-149.

Hagglund, S., Svensson, C., Emanuelson, U., Valarcher, J. F. and Alenius, S. (2006): Dynamics of virus infections involved in the bovine respiratory disease complex in Swedish dairy herds. Vet. J. 172, 320-328.

Hamers, C., Dehan, P., Couvreur, B., Letellier, C., Kerkhofs, P. and Pastoret, P. P. (2001): Diversity among bovine pestiviruses. Vet. J. 161, 112-122.

Houe, H. (1999): Epidemiological features and economical importance of bovine virus diarrhoea virus (BVDV) infections. Vet. Microbiol. 64, 89-107.

Houe, H. (2003): Economic impact of BVDV infection in dairies. Biologicals 31, 137-143.

Kahn, C. M. and Line, S. (2010): The Merck Veterinary Manual. Merck \& Co. Inc., Whitehouse Station, N. J.

Laureyns, J., Ribbens, S. and de Kruif, A. (2010): Control of bovine virus diarrhoea at the herd level: Reducing the risk of false negatives in the detection of persistently infected cattle. Vet. J. 184, 21-26.

Lindberg, A. L. E. and Alenius, S. (1999): Principles for eradication of bovine viral diarrhoea virus (BVDV) infections in cattle populations. Vet. Microbiol. 64, 197-222.

Lindberg, A., Brownlie, J., Gunn, G. J., Houe, H., Moennig, V., Saatkamp, H. W., Sandvik, T. and Valle, P. S. (2006): The control of bovine viral diarrhoea virus in Europe: today and in the future. Rev. Sci. Tech. Off. Int. Epiz. 25, 961-979.

Majer, J., Hornyák, Á., Ózsvári, L., Bárdos, K. and Szabára, Á. (2014): BVDV infection of a largescale diary cattle herd during grazing [in Hungarian, with English abstract]. Magyar Állatorvosok Lapja 136, 277-285.

Orban, S., Liess, B., Hafez, S. M., Frey, H. R., Blindow, H. and Sasse-Patzer, B. (1983): Studies on transplacental transmissibility of a Bovine Virus Diarrhoea (BVD) vaccine virus. I. Inoculation of pregnant cows 15 to 90 days before parturition (190th to 265th day of gestation). Zbl. Vet. Med. B 30, 619-634.

Ózsvári, L., Bíró, O. and Csaba, I. B. (2001): Quantification of losses caused by bovine viral diarrhoea and mucosal disease [in Hungarian, with English abstract]. Magyar Állatorvosok Lapja 123, 555-560.

Radostits, O. M. and Done, S. H. (2007): Veterinary Medicine: A Textbook of the Diseases of Cattle, Sheep, Pigs, Goats, and Horses. 10th edition. Elsevier Saunders, New York.

Ridpath, J. F. (2010): Bovine Viral Diarrhea Virus: Global status. Vet. Clin. North Am. Food Anim. Pract. 26, 105-121.

Szabára, Á. and Ózsvári, L. (2013): The prevalence, economic losses and eradication programs of BVDV in Europe [in Hungarian, with English abstract]. Magyar Állatorvosok Lapja 135, 285-292.

Vilcek, S., Mojzisova, J., Bajova, V., Paulik, S., Strojny, L., Durkovic, B. and Hipikova, V. (2003): A survey for BVDV antibodies in cattle farms in Slovakia and genetic typing of BVDV isolates from imported animals. Acta Vet. Hung. 51, 229-236. 